\title{
A Survey on the Incidence of Red Spider Mite (Tetranychus spp) aroud the Lake Chad Shore Area of Nigeria
}

\author{
U.M. Maina ${ }^{1}$, B.M. Sastawa ${ }^{2}$ and M. Lawan ${ }^{2}$ \\ ${ }^{I}$ For correspondence; Department of Agricultural Technology, Ramat Polytechnic Maiduguri P.M.B. 1070, \\ Maiduguri, Nigeria. \\ ${ }^{2}$ Department of Crop Protection, Faculty of Agriculture, University of Maiduguri, P.M.B.1069, Maiduguri,
} Nigeria

\begin{abstract}
Spider mite belongs to the family Tetranychidae that comprise a huge number of different species that attack a wide range of plants. A survey was conducted to gather information about spider mite around the Lake Chad shore area of Nigeria. The aim was to report the status of spider mite on horticultural crops, the amount of loss that is associated with the infestation and to find out the measures being taken by farmers in controlling the pests. A preliminary survey was conducted by visiting and inspecting farms around six villages (Daban masara,Daban giwa,Gapchari,Dumba,Baga and Doro) in the Lake Chad shore area before the focus was centered on Baga and Dumba where the mites are found. Using structured interview method, a sample size of 62 farmers was interviewed around the two villages. The farmers were selected at random and interviewed on their farms. The information gathered revealed that red spider mite (Tetranychus spp)was found to have been a major pest on egg plant and tomato since the year 2006 around Baga and Dumba in the Lake Chad shore area of Nigeria. More than 50\% loss of yield on eggplant has been recorded. To reduce this huge loss of yield, farmers in the area use insecticide spray as their major control measure. Some $20 \%$ of them use ordinary water spray in addition to insecticides. Thorough sanitation and burning of plant debris after each cropping season reduces the incidence spider mite infestation.
\end{abstract}

Key wards: Spider mite, eegplant, survey, Lake Chad shore

\section{Introduction}

Spider mite (Tetranychus spp) belongs to the family Tetranychidae of the order Prostigmata. The family Tetranychidae is one of the most important families of the Acarina because many species can be serious pests of agricultural crop (Faith et al., 2009). This family comprises a large group of about 1250 phytophagous species (Migeon et al., 2006) and their damage has been reported in ornamentals, horticultural crops, fruit crops and some staple food crops (Jeppson et al., 1975). Virtually any plant may be subjected to attack and economic damage caused by spider mites, because of their broad host plant range, high fecundity and rapid development rate (Faith et al., 2009). The majority of damaging species belong to the genus Tetranychus which are found on an extremely wide range of host plants including cotton, tobacco, tomato, potato, soybeans, eggplant and ornamentals (Keizer and Zuurbier, 2001).

Spider mite is a cosmopolitan pest and is broadly divided into two; the European red spider mite and Southern spider mite. The Southern red spider mite is the most common in Africa (Keizerand Zuurbier, 2001). The mite can be spread by wind and experience learned that the infestation often start on the outside (border rows) of the plot. Therefore, other adjacent crops, wild plant and weeds can serve as source of infestation (Keizer and Zuurbier, 2001). Irrigation water, dust storms and implements can also spread the mite passively. Tetranychus spp was accidently introduced in South Africa during the 80's from Brazil (Keizer and Zuurbier, 2001). Since its introduction in South Africa, the mite is slowly moving northwards. Nowadays it is one of the major constraints in tomato production in Mozambique, Malawi, Namibia, Zimbabwe and Zambia. Tetranychus spp was found around Ibadan in Nigeria in 1975(Matthysse and Denmark, 1981).

The mite is now a pest on horticultural crops around Baga and Dumba in the Lake Chad Basin area of Nigeria. There has not been any report in the past about the red spider mite around the Lake Chad shore area. Preliminary survey revealed that more than 50\% loss of yield on eggplant and tomato has been recorded in the field. In an attempt to contain the pest, farmers spray insecticides (Lamda-cyholathrin, Dichlorvus) at an interval of 2-3 days. The tiny nature of the pest has made it easy to be spread by wind over large area within short time and this has undermined the success of chemical control in the area. Also the rate and concentration at which the insecticides are applied is likely to put the consumers of vegetable at the risk of being poisoned.

Reporting this pest problem will create awareness among farmers and researchers to look for appropriate measures of controlling the pest. This report will also be a stepping-stone for any researchers who may wish to search for a better way of controlling the pest. Most importantly, any better way of controlling this pest that will be developed in the area, will significantly increase the yields of eggplant and tomato, which will 
significantly increase the income of the farmers. Furthermore, consumers will be saved from insecticide poisoning. The objectives of the study are; to carry out a survey on the incidence of spider mite (Tetranychus spp) in horticultural crop around Lake Chad shore area of Nigeria, to find out the amount of yield loss on the crops infested in the area, and the measures taken by farmers in controlling the pests.

\section{Study area}

\section{Materials And Methods}

The survey was conducted on Baga and Dumba where the pest problem is centered. Baga and Dumba are about $4 \mathrm{~km}$ apart and are both situated on an elevated sandy grounds in the Lake Chad shore plain of Nigeria. Farmers grow vegetable like eggplant, tomato, okra onion etc by irrigation using water from tube-well drilled in the farm.

\section{Data Collections}

Information was gathered through a structured interview. Questions of the interview were designed to meet the objectives of the study. Farmers around Baga and Dumba were interviewed on their farms. However, preliminary survey was conducted by visiting and inspecting farms around six villages (Dabam masara, Daban giwa, Dumba, Gapchari, Baga and Doro) before the focus was centered on Baga and Dumba for interview. A sample size of 62 farmers was selected from the two villages. Farmers were selected at random and interviewed. Their responses were quantified and analyzed using descriptive statistics.

\section{Result}

Cultivation of horticultural crops is wide spread among different age groups of farmers around the Lake Chad shore area. Farmers within the age of 31-45 made up 50\% of those interviewed while 30\% are above 45 years and the rest (20\%) are within 15-30 years (Table 1). Most of the farmers (80\%) have attended informal education school (tsangaya) and only few (20\%) have attended primary school (Table 1). Some of the farmers $(40 \%)$ interviewed are migrant farmers who mostly are from northwestern part of the country but majority of them are non-migrant farmers. Majority of the farmers (50\%) stated that the red spider mite was first noticed as a pest in the year 2006 while few (5\%) of them noticed the mite presence about 2 years earlier than the year 2006 (Table 2). Most of infestation starts at the nursery level. The mites were first seen on eggplant and later spread to tomato and few other crops (Table 3). On eggplant and tomato, the mites are now causing more than $50 \%$ yield loss (Table 4). Spray intervals have been shortened to $2-3$ days by $80 \%$ of farmers (Table 5). Apart from synthetic insecticides used by $80 \%$ of the farmers, few (20\%) use cultural method (spry of water) in addition to insecticides.

\section{Discussion}

Spider mite of the genus Tetranychus which is popularly known as spider mite because of it association with webbing, is a major pest on horticultural crops around Baga and Dumba in the Lake Chad shore area of Nigeria. The mites were first seen in the year 2004 on eggplant around Baga before spreading to Dumba. The mite reached pest status in the year 2006 and since then, it has been a major problem in eggplant and tomato production. However, 50\% of the farmers interviewed recorded more than $70 \%$ loss. Yield loss due to spider mite damage on eggplant and tomato is more than $50 \%$. This is a huge loss which farmers cannot continue to bear. Most of the pest attack begins at nursery stage in late establishment while attack occurs before flowering in early planting. Control of spider mite is difficult because of their rate of fecundity, rapid development and rate of development of resistance to miticide. In a struggle to control the pest, farmers apply insecticides at short intervals and high concentration. Few of the farmers use cultural method in addition to the insecticide. The method use in addition to the insecticides is the use of water spray on the plants which keep the plants moist and lower the temperature of the surrounding. This reduces the activities of the mite and then exposes them to have contact with insecticide if application is done few hours later.

\section{Conclusion}

This study confirmed that spider mite (Tetranychus spp) is a pest on eggplant and tomato around Baga and Dumba in the Lake Chad shore area of Nigeria. Due to the pest damage on eggplant and tomato, farmers have recorded a loss of more than $50 \%$ in the field. Also the study has gathered that, farmers use insecticides (Lamda-cyholathrin and Dichlorvus) spray as a measure of controlling spider mite in egg plant and tomato. In addition, ordinary water spray is also use as a control measure.

\section{Recommendations}

1. Farmers should be made aware of the importance of keeping farm free from weed and surrounding wild plants as a good cultural control method. 
2. Research should be conducted to identify the specie of the spider mites that are infesting horticultural crops in the area.

\section{References}

[1]. Aponte, O and McMutry, T.A. (1997) Biology, life table and mating behavior of Oligonychus perseae (Acari: Tetranychidae). International Journal of Acarology, 23: 199 - 207.

[2]. Faith, J. Toroitich, Edward A. Uecker Mann, Pieter D. Theron and Markus Knapp (2009) The Tetranychid mite (Acari: Tetranychidae) of Kenya and a redescription of the species Peltanobia erosmusi, Meyer (Acari: Tetranychidae) based on males. Zootaxa 2176: 33-47

[3]. Jeppson, L.R., Keifer,H.H. and Baker, E.W. (1975). Mite injurious to economic plant. University of California press, 24, 614pp

[4]. Keizer, M. and Zuurbier, J. (1999) Integrated Pest Management for Extension staff. Mashare Agricultural Development Institute, Rundu Namibia.

[5]. Keizer, M. and Zuurbier, J. (2001) Red spider mite. Namibian Crop Pest. 37, 21-26

[6]. Matthysse, J.G. and Denmark, H.A (1981). Some Phytoseiids of Nigeria (Acari: Mesostigmata). Florida entomology, 64 (2), $340-357$

[7]. Migeon,A., Ferragut, F., Escudero-Colomar, L., Fiaboe,K.,Knapp,M.,de Moraes,G.,Ueckermann,F.and Navajas,G.(2009) Modeling the potential distribution of the invasive tomato red spider mite,Tetranychus evnsi (Acari: Tetranychidae). Experimental and Applied Acarology, 48: 199-212.

[8]. Smiley, R.L. and Baker, E.W. (1995), A report on some spider mite (Acari: Prostigmata) from Yemen. International Journal of Acarology, 21,135 - 164

Table1. Percentage of farmers of different age and educational level

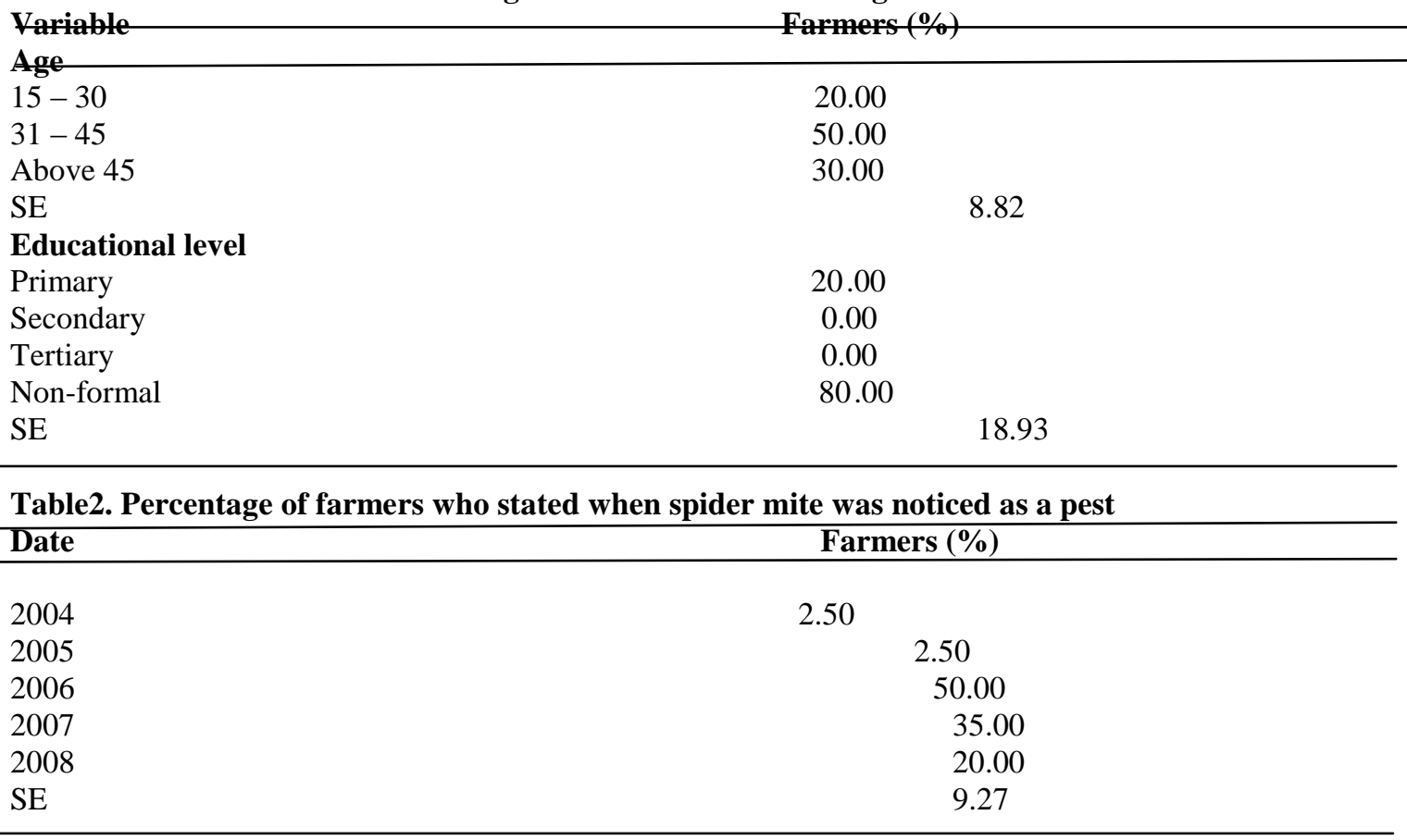

Table3. Percentage of farmers that have listed the susceptible crops to spider mite

\begin{tabular}{lcc} 
Crops & Farmers (\%) & \\
Egg plant & 100.00 & \\
Tomato & 95.00 & \\
Pepper & 5.00 & \\
Iris potato & 5.00 & \\
Onion & 0.00 & 23.09 \\
SE & & \\
\hline
\end{tabular}

Table4. Percentage of farmers that have stated various percentages of losses due to spider mite on eggplant

\begin{tabular}{cc} 
Loss $(\%)$ & Farmer $(\%)$ \\
\hline 50 & \\
60 & 30.00 \\
70 & 15.00 \\
80 & 10.00 \\
90 & 25.00 \\
100 & 25.00 \\
& 0.00
\end{tabular}


A Survey on the Incidence of Red Spider Mite (Tetranychus spp) aroud the Lake Chad Shore Area of SE 4.61

Table5. Percentage of farmers that use different spray intervals.

Spray interval (days)

Farmers (\%)

$2-3$ 80.00

$4-5$

$6-7$

15.00

Over one week

5.00

SE

18.59 